\title{
ISOTOPIC AND GEOCHEMICAL VARIATION IN KIMBERLITES FROM THE SOUTH WESTERN CRATON MARGIN, PRIESKA AREA, SOUTH AFRICA.
}

\author{
Clark, ${ }^{(1,2)}$ T.C.; Smith, ${ }^{(1)}$ C.B.; Bristow, ${ }^{(3)}$ J.W.; Skinner, ${ }^{(3)}$ E.M.W and Viljoen, ${ }^{(3)}$ K.S.
}

(1) Bernard Price Institute for Geophysical Research, U. Witwatersrand, Johannesburg 2050, R.S.A.; (2) GENMIN Laboratories, Springs 1560, R.S.A.; (3) Anglo American Research Laboratories, Box 106, Crown Mines 2025, R.S.A.

Approximately 130 known kimberlite bodies occur in a broad belt from northwest of Prieska to Sutherland in the northern part of the Cape Province (see location map in Skinner et al., this volume). Being situated peripherally to the Kaapvaal Craton, the kimberlites generally lack diamond, comprise both micaceous and non-micaceous types as defined by Skinner (1989), and were emplaced during at least five separate periods beteen 74 and $140 \mathrm{Ma}$ (Skinner et al., this volume).

Age-corrected Nd and Sr whole-rock isotopic ratios indicate that both Group I and Group II varieties as defined by Smith (1983) are present, as well as an additional, probably subsidiary variety with transitional isotopic character (Fig. 1). Group I kimberlites include Uintjiesberg, Britstown, Violkraal West, and Hartebeesfontein, and have initial ${ }^{87} \mathrm{Sr} / 6 \mathrm{Sr}$ and ${ }^{143} \mathrm{Nd} /{ }^{144} \mathrm{Nd}$ ratios of .7035 to .7045 and about .51265 , respectively, very typical of other Group I kimberlites. The Pampoenpoort kimberlite has a significantly lower initial Nd isotopic ratio near bulk earth in composition, and in this regard is very similar to the Frank Smith kimberlite from the Barkly West district near Kimberley. Emplacement events for the Group I bodies occurred at about 74, 100 and $114 \mathrm{Ma}$., and the kimberlites occur dominantly in domains I, II and IV of the Prieska area as defined by Skinner et al. (this volume).

Group II kimberlite emplacement occurred dominantly between 114 and 120 Ma with a possible earlier event at $126 \mathrm{Ma}$, and include Markt, Middlewater, Jonkerwater, Brandewynskuil, Eendekuil, Slypsteen, Welgevonden, Witberg East dyke, Silvery Home and Sandrift. Initial Sr isotope ratios range from .7075 to .7090 , and initial $\mathrm{Nd}$ isotope ratios range from .5119 to nearly .5122 (Fig. 1). These kimberlites are situated in domains I, II and III (Skinner et al., this volume), with the majority apparently in III, an area bounded by the Brakbos and Dornberg faults. Insofar as the latter is generally taken to be the Kaapvaal Craton boundary, those kimberlites may be defined as off-craton. However, domain III is underlain by crust of apparent Archaean age of uncertain relation to the Kaapvaal (Cornell et al., 1986). The Group II kimberlites in this domain tend to have somewhat less radiogenic $\mathrm{Nd}$ isotopic compositions for a given $\mathrm{Sr}$ isotopic composition compared to other Group II localities, but are otherwise not isotopically distinctive compared to occurrences from within the bounds of the Kaapvaal Craton.

Several occurrences of micaceous kimberlite have isotopic, petrographic and geochemical features transitional between Group I and Group II types. The kimberlites include Skietkop, Sweetput-Soutput, Droogfontein and Melton Wold and apparently occur largely in domain V of the area except for Sweetput-Soutput (domain II). Emplacement ages are not well constrained (Skinner et al., this volume); Sweetput-Soutput is about $115 \mathrm{Ma}$ in age, but the others could be significantly older according to perovskite dating. Initial $\mathrm{Sr}$ and $\mathrm{Nd}$ isotopic ratios respectively vary from .7055 to .707 and from .51215 to .51235 , with two Melton Wold samples having the most radiogenic Nd and highly variable Sr isotopic compositons (Fig. 1). Previous studies of cratonic kimberlites have indicated that samples with transitional $\mathrm{Sr}$ isotopic features were altered and/or contaminated, but the samples analyzed in this study are fresh and the transitional features are a primary component that therefore reflects source composition. 
Whole-rock geochemical analyses of the kimberlites show similar major, minor and trace element patterns to their cratonic counterparts (e.g. Smith et al., 1985). Group I kimberlites contain (on average) less $\mathrm{SiO}_{2}, \mathrm{Al}_{2} \mathrm{O}_{3}, \mathrm{Na}_{2} \mathrm{O}, \mathrm{Ba}, \mathrm{Rb}, \mathrm{Sr}, \mathrm{Cr}, \mathrm{Ni}$ and $\mathrm{REE}$ contents than Group

II rocks. $\mathrm{K}_{2} \mathrm{O}$ and $\mathrm{TiO}_{2}$ contents are particularly good discriminators (Fig. 2), being a function of the mineralogical differences between the types, and showing the group distinctions very similar to those noted by Smith et al. (1985). There are few apparent and significant differences between on- and off-craton kimberlites of either Group I or Group II, although cratonic Group I kimberlites tend to have higher Th/U than off-craton Group I, and off-craton Group II kimberlites have significantly greater LREE cnrichment compared to off-craton Group I. The distinction in REE patterns between Groups I and II is not apparent in the on-craton setting.

The isotopically defined transitional kimberlites also have transitional geochemical features. In Fig. 2 the transitional kimberlites plot in the Group II field in keeping with their micaceous character, but they also have somewhat elevated $\mathrm{TiO}_{2}$ in keeping with abundant perovskite (not generally present in on-craton Group II). As regards REE abundances, the transitional rocks are similar to Group II for the LREE, but more akin to Group I for Yb.

The isotopic and geochemical characteristics of these kimberlites are consistent with derivation of Group I rocks from sub-lithospheric plume sources, while Group II sources could reside in ancient enriched lithosphere, or could also occur in DUPAL-like asthenospheric plume sources. The transitional kimberlites are apparently derived from mixed source regions, a process possibly enhanced in areas of thinner lithosphere presumably corresponding with the craton margin. While this does not preclude plume sources for either Group I or II kimberlites, the presence of the transitional rocks may also be consistent with the creation of their sources from mixed asthenospheric and ancient lithospheric domains during Proterozoic crust/lithosphere formation represented by the Namaqua Province.

\section{REFERENCES}

Cornell, D., Hawkesworth, C.J., van Calsteren, P., and Scott, W.D. (1986) Sm-Nd study of Precambrian crustal development in the Prieska-Copperton region, Cape Province. Trans. Geol. Soc. S. Africa 89, 17-28.

Fraser, KJ. (19873) Petrogenesis of kimberlites from South Africa and lamproites from Western Australia and North America, $\mathrm{PhD}$ thesis, Open University.

Skinner, E.M.W. (1989) Contrasting group I and Group II kimberlite petrology: towards a genetic model for kimberlites. In J. Ross, Man. ed., Kimberlites and Related Rocks, Their Composition, Occurrence, Origin and Emplacement, Geol. Soc. Australia Spec. Publ. 14, p. 528-544.

Skinner, E.M.W., Viljoen, K.S., Clark, T.C., Smith, C.B., and Bristow, J.W. (this volume) The geology of kimberlites in the south western border region of the Kaapvaal Craton, Prieska area, South Africa.

Smith, C.B. (1983) $\mathrm{Pb}, \mathrm{Sr}$ and Nd isotopic evidence for sources of southern African Cretaceous kimberlites. Nature 304, 51-54.

Smith, C.B., Gurney, J.J., Skinner, E.M.W., Clement, C.R., and Ebrahim, N. (1985) Geochemical character of southern African kimberlites: A new approach based on isotopic constraints. Trans. Geol. Soc. S. Africa 88, 267-280.

Spriggs, A.J. (1988) An isotopic and geochemical study of kimberlite and associated alkaline rocks from Namibia, $\mathrm{PhD}$ thesis, University of Leeds. 


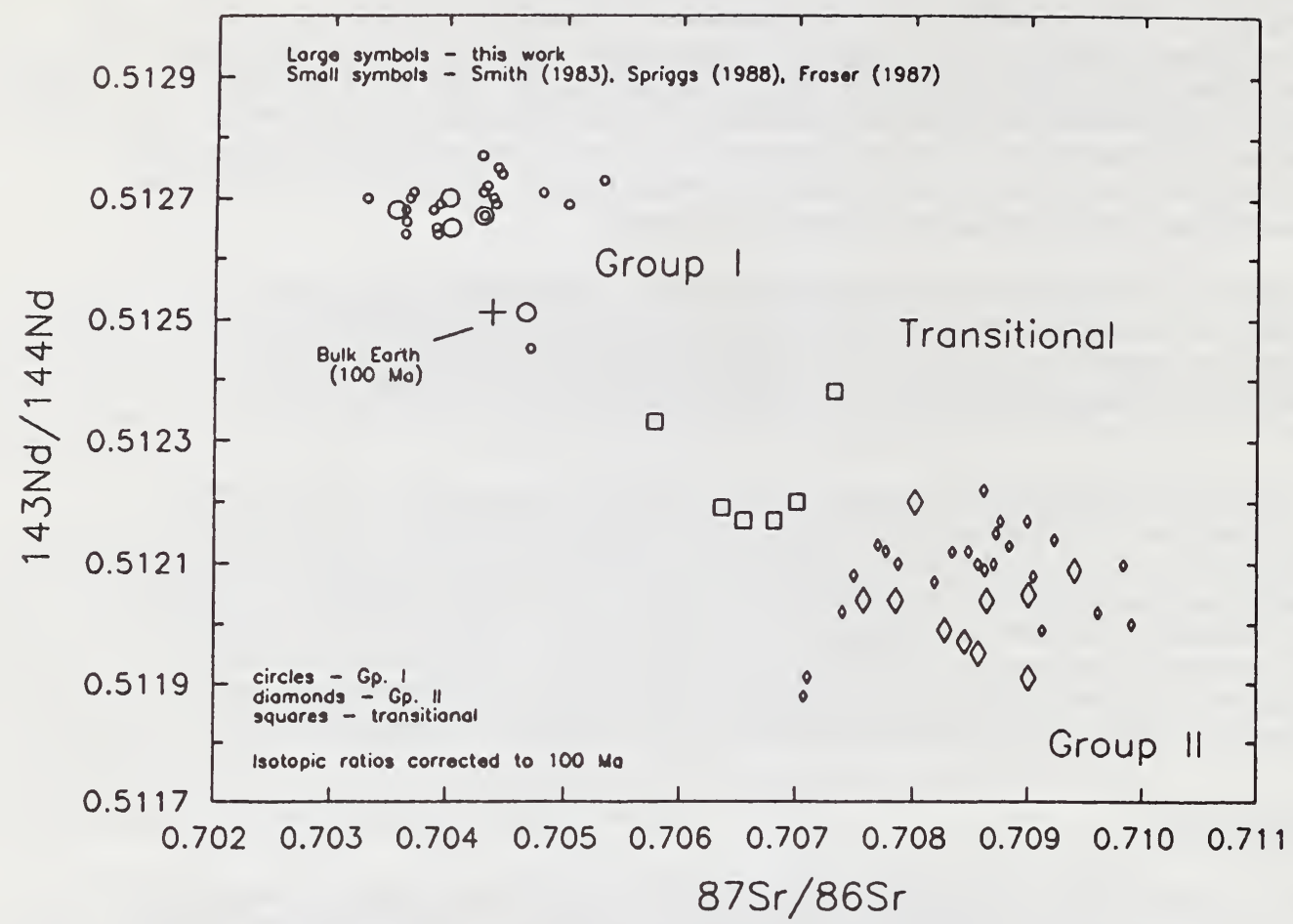

Figure 1. Nd-Sr isotope correlation diagram for Prieska kimberlites.

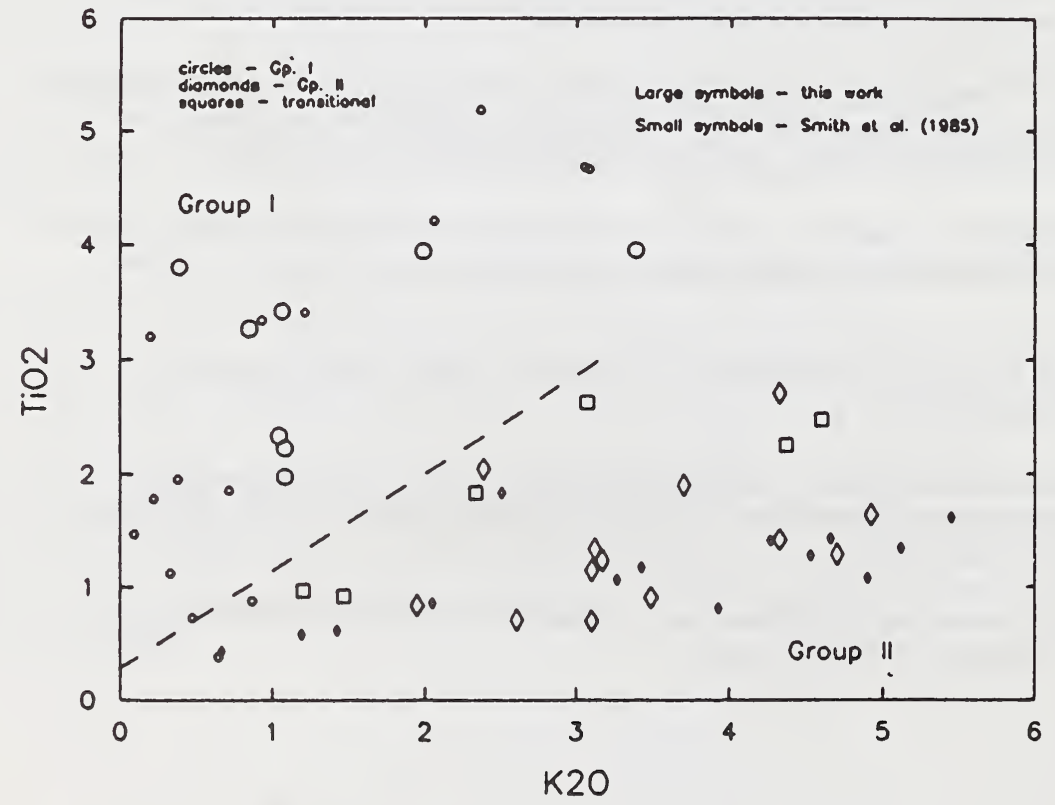

Figure 2. $\mathrm{TiO}_{2}$ vs. $\mathrm{K}_{2} \mathrm{O}$ for Prieska kimberlites. 